\title{
Article
}

\section{The Languages We May Be: Affiliative Relations and the Work of the Canadian Writing Centre}

Frankie Condon

University of Waterloo

\section{Abstract}

This essay explores the possibility of imagining Canadian writing centres as sites wherein the Canadian commitment to multiculturalism and human rights may be more fully enacted and our country's historical injustices may be addressed through the collective labours of writing centre scholars, directors, and tutors.

Keywords: cultural competence, multilingualism, social justice, writing centre pedagogy

\section{Introduction}

This essay began as a keynote address for the Canadian Writing Centres Association Conference and was delivered in the traditional territory of the Haudenosaunee, the Métis, and most recently, the territory of the Mississaugas of the New Credit First Nation. The territory was the subject of the Dish With One Spoon Wampum Belt Covenant, an agreement between the Iroquois Confederacy and the Ojibwe and allied nations to peaceably share and care for the resources around the Great Lakes.

To offer a territorial acknowledgement in some meaningful way as a settler as well as an aspiring new Canadian requires something more than simply to say "this is where we are." The acknowledgement is attended by responsibility: to speak the truth as best we can discern it in this moment and to treat with respect this place, its history, and its peoples. When we speak with or write to one another even and especially in professional contexts, we have an opportunity not merely to produce new knowledge from within traditional settler contexts but to transform those contexts, deepening all our relations, extending and thickening our sense of affiliation beyond those for whom our institutions and institutional sites have historically been designed and whose interests have been historically served by them. 
Volume 28, 2018

http://journals.sfu.ca/cjsdw

My objective in this essay is to explore the possibility of imagining Canadian writing centres as sites wherein the Canadian commitment to multiculturalism and human rights may be more fully enacted and our country's historical injustices addressed through our collective labours. There are certainly dangers in such an approach to the work of writing centres. In my experience, in fact, in the work of social justice, generally, and of racial justice, in particular, failures are inevitable. But it is the fear of failure that represents the greatest obstacle to both social and institutional change, for it is that fear which pins us to the known and agitates us so that we cannot imagine worlds and ways of possibility beyond what we have known. Fear of failure more than the fact of failure prevents us from beginning even the most tentative of exercises in imagination-and effort. To begin such work requires that writing centre leaders and staff dedicate ourselves to the nourishment of emerging relations and act courageously in service of these relations to change ourselves, our writing centres, and our institutions. I hope that readers will join me in accepting the responsibility that attends recognition of the sacredness of Turtle Island and of all our relations in the places where we live and labour.

As an aspiring new Canadian, I felt grateful and tremendously honoured to have been offered the opportunity to deliberate on the relationship between Canada's past, the work of writing centres in the present, and to imagine with conference attendees the work of writing centres within the context of Canada's expressed commitments to human rights, to truth and reconciliation, to rich and deep valuation of diversity, and to creating and sustaining a compassionate and humane nation. As I prepared for the day of the conference, however, I found myself wondering how it was that I, an expat American albeit one who really, really wants to be Canadian should be the one delivering the keynote address of the CWCA in the $150^{\text {th }}$ anniversary year of Canada's Confederation. There was a curious resonance for me between this occasion and a moment long ago, in 1980, when I was admitted to York University's BFA program in theatre performance.

That program's mission as I understood it was to develop a Canadian theatre culture and tradition distinct from the imperial(ist) influences of both the United Kingdom and the United States: to cultivate Canadian playwrights, Canadian acting methods, and Canadian actors. I've never been quite sure why they let me into that program at all, let alone admitting me in what was its inaugural year. I felt lucky, blessed-as indeed I did at the CWCA conference-and also hopeful that perhaps I might slip through before the university or the Theatre Department figured out that they'd accidentally installed an American in their beautiful new program. 
Volume 28, 2018

http://journals.sfu.ca/cjsdw

As an undergraduate at York, I was, perhaps, too caught up in the drama of my dream to be an actor, too self-absorbed, and too young, frankly, to understand what was particularly Canadian about my education as an actor or my experience at York, in general. My Canadian friends were more cosmopolitan, perhaps, than my friends at home, more worldly, and better educated. As diverse as York was even then in comparison to my home community in rural western Pennsylvania, the students with whom I lived in residence did not seem to me to be more tolerant of difference than the kids I grew up with, nor did they strike me as being notably less racist or xenophobic. Certainly, they knew and used liberally the same racial epithets as kids in my home community. In terms of course work, in History, I took a course on Tudor and Stuart England. In English, I took a course on the British Romantic poets. In acting classes, we studied methods developed by Konstantin Stanislavsky, Jerzy Grotowsky, and Michael Shurtleff-all non-Canadians. Within our program, our cohort performed only one play written by a Canadian playwright: "Narnia," which was, of course, based on the C.S. Lewis book The Lion, the Witch, and the Wardrobe. In hindsight, I believe York University's Theatre Department had begun a project of collective imagination and had not yet discerned how their emerging vision might be realized. And so we were trained according to the known even as we were asked to engage with the creation of a theatre as yet unknown. And because we were young and smart, dedicated, and determined, many of us made good on that great experiment. This is typical not only of institutional change initiatives, but also of institutional efforts to not be someone or something else. To fall back on what we know even when we have placed ourselves in the unknown and tasked ourselves with imagining and testing new ideas, principles, and practices seems quite common to me within higher education. But it is insufficient, I think, to rely on the ingenuity of our students to figure out how to do what we have imagined for them.

The machinery of universities is far slower to move in response to new and important ideas than those of us who make their lives within them like to acknowledge. Historically, of course, the work of universities has been to conserve knowledge as much as to produce it: to act not only as loci for the production of new knowledge, but also and especially as repositories for the known. Each successive generation of scholars has been tasked with ensuring that however scarce the knowledge-making economy might be, the conditions for maintaining the known are preserved. It is perhaps this conservationist root of European and North American higher education that impedes the mobility of our universities, their capacity to change adeptly in response to new or transforming social imperatives. 
Volume 28, 2018

http://journals.sfu.ca/cjsdw

But there is something more. That which the universities of imperial and colonial powers have historically sought to conserve and pass forward are most often the very languages, knowledgemaking and rhetorical traditions, histories, philosophies, and worldviews through which political struggles for power, domination, and ownership have been and continue to be waged. In his book Linguistic Imperialism, Robert Phillipson (1992) traces the systematic ways in which the official languages of imperial powers historically have been deployed in service of colonization. Canada is a nation forged in the crucible of colonialism - a nation in which language has historically been instrumentalized to claim, hold, and exert power over and against the colonized, the marginalized, and the oppressed. In the 150th year since Confederation, even as we, scholars and teachers of language, of writing and communication studies, celebrate, we might remember how language was deployed in power struggles between Anglophone and Francophone Canadians, the ways in which Francophones were racialized and so marginalized, their language, their cultural identification, and worldviews pathologized and suppressed. We might remember the epic struggle for recognition and political empowerment by French Canadians and acknowledge that that struggle is not yet fully resolved even though French is now one of our two official languages alongside if not co-equally with English. We might also recall that there have long been and are now increasing numbers of Other and Othered languages and with them Othered identities, cultures, worldviews, knowledge-making practices, and rhetorical traditions in Canada that we have yet to recognize, celebrate, and honour. What Phillipson doesn't say, but what is also true, is that the insistence upon and privileging of an official and dominant language or languages and concomitant devaluing of Indigenous and Othered languages within current or former colonial nations produces education systems that by design manufacture inequality. These are difficult times and we have a difficult history with which to contend-a history that continues to shape our present tenses and to bedevil our future possibilities.

However, I think writing centres are more adaptive, more mobile than the institutions that house them. While those who work within writing centres may feel at times (or frequently) that our work is little understood by faculty colleagues and little valued by our institutional leaders, I believe that writing centre folks are remarkably adept at recognizing opportunities to make significant changes, at finding and building strong and lasting alliances and collaborations with campus and community change agents, and at facilitating significant transformations from the grassroots. In a recent issue of the Writing Lab Newsletter, Clare Bermingham (2017) wrote that the 2017 CWCA conference theme asked presenters and participants to imagine how Canadian writing centres might make our national and local commitments to equity and inclusion real and actionable within our centres and across our 
Volume 28, 2018

http://journals.sfu.ca/cjsdw

universities. The call for papers for the conference, she noted, invited participants to begin to account in both theory and practice for the complex relationship between language and power as they manifest in the everyday lives of our students, conditioning their lived experience and shaping who, what, and how they may be and become-as scholars, as writers, as professionals, and as citizens of the world. I believe we are well positioned to do this work and to move from imagining to attempting change. The enabling condition for such an attempt on our part, as it was for my teachers so long ago at York, seems to me to be a willingness to draw upon what we know without being handcuffed to the known. To imagine doing our work differently requires a particular brand of courageousness, a willingness to experiment and to fail, and the determination to amend or revise and try again. To actually do our work differently will require that we learn to think differently. We will need to name the obstacles to our success honestly, neither underestimating nor exaggerating them.

Several years ago, while working on the manuscript for I Hope I Join the Band (Condon, 2012), I read a blog post by the British musician, Brian Eno, in which he tells the following story, as I subsequently related in the book as follows:

While sojourning in New York City during the late 1970s, Eno writes, he was invited by a wealthy socialite to a party at her Manhattan home. On the evening of the gathering, he climbed into a taxi and gave the driver the woman's address. The cab carried him, he says, through increasingly deserted streets to a part of Manhattan he had never seen nor known existed streets lined by derelict houses on whose stoops hunched the homeless, backs curled against the cold. And then by shuttered industries, darkened warehouses where no one seemed to live or to linger. He worried that he had gotten the wrong address. Or that the cabbie was plotting to rob him. At last, however, the driver pulled up to what had once been a warehouse and announced their arrival. Still wondering what he was in for, Eno describes ringing a doorbell, entering and ascending in an old delivery elevator that opened its doors at last to reveal an apartment of stunning opulence. The party, attended by the wealthiest patrons of the arts in the City, by their current favourite artists, and perhaps as well by a few fringe dwellers hoping to belong to such an auspicious set one day, was all brightness and tinkling glasses, champagne and light badinage. At one point, Eno says, he asked his hostess about her home, which she affirmed to him was the best place she'd ever lived. He asked whether she liked living in such a neighbourhood and writes that she replied, "Oh, the neighbourhood. Well, that's outside." 
Volume 28, 2018

http://journals.sfu.ca/cjsdw

Eno describes being struck by the incongruence of such a remark with his own sense of place. "How could you not think of where I live as including at least some of the space outside your four walls, some of the bits you couldn't lock up behind you?" he ponders. And he terms this particularly bounded sense of place "the small here." Eno narrates becoming increasingly aware of a parallel perspective on time driven by the conviction that what matters is what is exciting or provocative, useful or expedient in the most immediate sense: a perspective he came to believe was reckless, dangerous, and irresponsible. And so Eno came to think also about what he terms, "the long now". "The Long Now," he writes, "is the recognition that the precise moment you're in grows out of the past and is a seed for the future. The longer your sense of Now, the more past and future it includes." Eno goes on to suggest that the bigger your sense of Here and longer your sense of Now the more extended are your relations; the more significant your responsibilities to those who came before and to successive generations the more fully must those responsibilities condition how you think and what you do in the present. (pp.125-126)

Canadian writing centres, like the institutions in which they are located, are challenged, it seems to me, by the tensions between the Small-Here/Short-Now expediencies of a political economy (our job is to prepare students to enter the professions, to produce a living for themselves and wealth for the nation) and the Big-Here/Long-Now imperative to more fully realize and make actionable a political philosophy that emphasizes social justice, human rights, inclusion, and deep affiliation among and between peoples across lines of difference within and beyond our nation's borders. We are charged with facilitating student writers' fluency and adeptness not only with our official languages, and more especially with particular forms of those languages -with what is frequently referred to as "Edited Academic English." But this means that we are also charged with monitoring and managing the incursions of "unofficial" and "illegitimate" cultures, identities, and worldviews into the strictly circumscribed domains of the official and the legitimate. We are, all of us, the languages we speak; we cannot split off language from identity. To the extent that we are called upon to stand on guard not only for our national official languages, but for particular, elite forms of those languages, we are called upon to be functionaries, willing or not, of exclusion. We cannot with any reasonable justification represent our work as writing centre directors and tutors as being politically neutral, ideologically inert, or historically innocent of complicity with the forces of colonialism and its aftermaths in Canada. And so, to imagine a future for Canadian writing centres in which our 
Volume 28, 2018

http://journals.sfu.ca/cjsdw

practices more fully and increasingly reflect our commitment to equity and inclusion, will require that we recognize the tension between the Small-Here/Short-Now work we may feel obligated to do and the Big-Here/Long-Now implications of that work.

As fraught as our national history may be, however, there are principles or qualities deeply embedded in Canadian identity writ large from which the nation may draw to create more just futures as allies of and collaborators with Indigenous peoples and new Canadians currently marginalized by virtue of their racialization, nations of origin, cultural identifications, religion, gender, and home language or languages. Similarly, Canadian writing centres may draw upon these, too, as we create more inclusive learning environments, more equitable teaching practices, and more fair and just relations within our centres and our universities.

Four years ago, while preparing to return to Canada-this time for keeps, I hope-to take up my new position at the University of Waterloo, I received a gift in the mail. My friend and colleague, Jay Dolmage had sent me a copy of John Ralston Saul's book A Fair Country: Telling Truths About Canada (2008). Without rehearsing the finer points of Saul's argument too closely, I'll say this: Saul writes that Canada has long distorted and mythologized the sources of inspiration for our political and social arrangements, our civilization. Although, he says, we have told ourselves and taught our children to believe that what we are as a nation is inspired by British or French or European models, we are rather, he writes, "a people of Aboriginal inspiration organized around Indigenous concepts of peace, fairness, and good government" (pp. xv - xvi). Canada is, and by extension Canadians are, he argues, a Métis civilization and this historical mixture, this web of affiliative relations has produced a political philosophy-if not its realization-grounded in principles of equity and welcome, moderation and wisdom, a tolerance for complexity and ambiguity, patience and an attending willingness to both work and to wait for that consensus achievable through balanced and fair relations. Saul suggests that we subvert our ability both to draw upon these resources and to more fully manifest the quality of society they should enable us to create together to the extent that we "insist on describing ourselves as something we are not" and on behaving as if that false description, or mythology, were true (p. xv). Saul quite particularly names Canadian universities as being complicit in the conservation of this mythology and in its promotion as we teach students that Canada's roots lie in British, French, and European language, political philosophy and cultural production.

But wait! I want to name these qualities Saul identifies as the undergirding principles of a Canadian Métis society again: equity and welcome, moderation and wisdom, a tolerance for complexity and ambiguity, patience and an attending willingness to both work and to wait for that 
Volume 28, 2018

http://journals.sfu.ca/cjsdw

consensus achievable through balanced and fair relations. These resonate profoundly with what I would think of as a Big-Here/Long-Now consciousness. But also, do not these qualities sound so much like qualities of the idealized writing centre space, time, and relations we might well already be striving to create and to sustain? Even as we are drawn, however, to such a vision of who we are and what we care about - whether we think about these qualities in the broader national context or as the enabling condition for socially just and responsible writing centre work-our enthusiasm may well be mitigated by our experience of trying and failing: institutional inertia is powerful. Our colleagues expect that we will focus our attention and our energy on teaching their students to write so they may focus their attention and energy on "content" (as if course content and student writing are unrelated). The tendency of our institutions and our colleagues to fail to recognize our field as a field, scholarship in our field as "rigorous" or valuable, to recognize us as scholars as well as teachers, tutors, and program administrators can be so very discouraging, not only because these things make us feel undervalued and disrespected but also because they possess a powerful gravitational pull that tightly grips and contains us and the work of our writing centres within the Small-Here/Short-Now. We also know intimately that sense of urgency and sometimes crisis that brings student writers to our centres convinced that they require and we can provide direct and immediate instruction in how to do all the things right all the time so they can get good grades, graduate, get good jobs, and make their parents proud. We understand how and why so many student writers possess such an instrumental view of written and oral communication. To learn fast how to get by might very reasonably seem like the most expedient way to avoid failure regardless of whether such an approach to the acquisition of knowledge results in any lasting and usable understanding, facility, or skill. On gloomy days or in darker moments, we may well despair that such principles could ever be authentically realized within our actual, muck-a-day institutions.

I want to call your attention, however, to an extraordinary essay entitled "Prisoners of Hope" by American scholar Cornel West (2005). In it, West writes of the bleakness of our historical moment, identifying wealth inequality and class polarization, a rising tide of white supremacy, xenophobia, and racism as conditions that empty us all of spiritual sustenance and moral fortitude. West does not condemn idealism that imagines and yearns for transformed and transformative futures, but argues that idealism evacuated of "courage and follow-through" will fuel the growing rage that burns not only among Black Americans, but also among marginalized and oppressed peoples around the world (para. 6). In this context, West makes a critical distinction between optimism and hope that is worth taking seriously. While "optimism," West writes, "adopts the role of the spectator who surveys the 
Volume 28, 2018

http://journals.sfu.ca/cjsdw

evidence in order to infer that things are going to get better...hope enacts the stance of the participant who actively struggles against the evidence to change the deadly tides of wealth inequality, group xenophobia, and personal despair" (para. 9). The real problem we face in trying to envisage what Canadian writing centres might be and do in the future is not our idealism, nor is it really the pessimism we may feel when we are discouraged, but rather the spectre of optimism, and the possibility that we might do nothing more than continue to affirm that things will get better without ever actually doing anything to make them better. Optimism, unfortunately, is easier than engaging in the work of figuring out what to do or how to do something.

We surely know by now that none but the most privileged among us grow up speaking and writing the English most valued and rewarded in university classrooms when students produce it. We know that grading schemes predicated upon prior knowledge and adherence to the prescriptive norms of Edited Academic English systematically advantage those who are already privileged, even when our most privileged students work less hard, challenge themselves not a whit, and, hence, learn less than their peers. Even John Ralston Saul, who is a philosopher and not a rhetorician or a writing studies scholar, understands the illogic of what pass for "standards" in language teaching and learning. If we accept Saul's articulation of the undergirding principles of Canadian political philosophy, to accept or advance such "standards" seems very nearly UN-Canadian, in fact. Saul (2008) writes that:

[Standards] come in many forms in varying civilizations. They are usually defined by the method and structure of particular civilizations...What we are dealing with here is not an attempt to link such standards through a search for shared underlying principles. Instead we are faced by the pretence of universal standards...what is really taking place is the adoption of one civilization's particular standards, based on their assumptions, by another civilization built upon quite different assumptions. In this way, fearful minds can pretend they are concerned by quality when what they are expressing is nothing more than provincial workshop of the empire's ways. (p. 73)

As if to affirm Saul's insight, many expert and renowned writers and speakers-scholarly, professional, and creative-routinely violate the prescriptions so often taught as inviolable rules to student writers...and are praised and rewarded for the quality of their prose. We know that racism, xenophobia, class, and gender prejudice precede the performance of fluency in Edited Academic English. That is, as Vershawn Ashanti Young (2010) most notably has pointed out, our students do 
Volume 28, 2018

http://journals.sfu.ca/cjsdw

not become the targets of discrimination because they fail to speak and write effectively in Edited Academic English; they are targets of discrimination because racism; because xenophobia; because sexism, homophobia, transphobia, nativism, hypernationalism; because linguistic prejudice.

On the other hand, we know that multilingualism is a powerful resource for student speakers and writers: that students who compose orally and textually in multiple languages or who braid their languages together within a single composition possess what Tomson Highway (2015) celebrates as a suppleness of mind: a kind of intellectual and, notably, cultural dexterity. To learn another's language is to learn in a deep and sustained way who they are, how they have come to be, their history, their culture, their ways of seeing and of making meaning in and of the world. To speak (and we might add, to write) only one language, Highway writes, "is like living in a house that has but one window...it is like sitting at a dinner table where you do all the talking and you talk about nothing but yourself. It means you're not listening to what the other person has to say. It means you are not interested." And that, he notes, is "not good for relationships" (pp. 33-34). The implications of Highway's insight are significant to our work in this sense: reciprocity. We can neither imagine alternative futures nor realize more equitable and inclusive teaching and tutoring practices within our writing centres if we cannot listen and are not interested in the multiple languages, rhetorical traditions, and knowledge-making practices in which our students are already fluent: that shape who they are and their relations. We cannot ally, collaborate, support, or teach those whom we are unwilling to know. A significant element of our ability to meet the challenges of creating more just, fair, and balanced conditions for learning within our centres depends upon our willingness to draw upon our own multiple fluencies and to extend them. Where relations are affiliative, where they are fair and balanced, there can be no bifurcation of need and provision: no dependence and thus indebtedness on one side and noblesse oblige on the other. The Big-Here/Long-Now alternative to a political economy framed in terms of the Small-Here/Short-Now is, I believe, a gift economy in which we both offer and receive, teach and are taught: an economy predicated not on individual success and advancement, but on the sharpening of our awareness of mutual contingence, an acceptance of our interdependence, and a deepening of our affiliations with and for one another across lines of difference.

Further, when we think of linguistic diversity as a resource for learning and reciprocal willingness to learn the languages and cultures of our students as a necessary condition for teaching them well, we might begin to recognize that we are not faced with an either/or situation: that to teach in ways that acknowledge and build upon the linguistic, rhetorical, and intellectual power that 
Volume 28, 2018

http://journals.sfu.ca/cjsdw

multilingualism cultivates does not mean we cannot also teach the languages, rhetorical tradition, and epistemological practices that our universities have historically valued. We might begin to notice, in fact, the ways in which those matters become more intelligible to students and practicable for them as writers when they are invited to parley their knowledge and facility with home languages, their identifications, affiliations, and worldviews into critical engagement with a language like Edited Academic English. We might begin to see that welcoming student-writers' playfulness within, among, and between languages provides an opportunity to explore with them how languages work, their grammaticalities, their idiosyncrasies and so to teach in invigorated ways agentful composition. We want-or we should want-to teach students to recognize and draw upon the fantastic array of structural and rhetorical choices available to them as they compose. We want-or we should wantto help students learn to recognize common genres and rhetorical situations, to know what readers

will have learned to expect. But we should never, ever teach or imply to students in our teaching that they have no power to move their readers, or that surprise, delight, or the unanticipated insight are flaws in speaking and writing. We should not teach students that they are slaves to the conventions of a dominant group's language and, hence, that in order to succeed in a society ruled by that group they must abandon and denounce their own languages, cultures, and identities.

Too often when faced with the unknown, the tendency for those of us raised up in an academic culture animated by the imperatives of colonialism and its aftermath to preserve and impose dominant languages, rhetorical traditions, and epistemologies has been either to declare the impossibility of change or to insist that someone or something else must change first. In so doing, however, we continue to demand that Othered peoples wait for inclusion without any attending commitment on our part to work on behalf of full inclusion. What if we, writing centre folks, actively eschewed the mythology surrounding "the language of power" and its relation to social and economic mobility and instead began to imagine and experiment with one-with-one pedagogical praxis that teaches speaking and writing in that very nexus of diverse languages, cultures, and world views that is the wellspring of a uniquely Canadian political philosophy and the source of our national identity? What if we abjured our fears and our doubts in order to explore alternatives to that which we have been taught to treat as the common sense of language, culture, and the production of knowledge?

\section{Conclusion: Imagination and Experimentalism}

I first visited and began to care deeply for Canada as a child. For many summers, my parents rented a cottage in a small lakeside resort near North Bay. We traveled sixteen kilometers by boat with all 
Volume 28, 2018

http://journals.sfu.ca/cjsdw

of our gear and stayed for two weeks at a time in a little grey cottage called Windy Point. For me, Canada was magical. I had, you see, read Anne of Green Gables. I was Anne of Green Gables. It little mattered to me whether Anne lived on PEI or along the shores of Clear Lake in Northern Ontario. The quality of light across the blue-green water, the forested and rocky shorelines, the sound of the wind in fir trees, and the smell of sunshine on the pine-needle carpeted floors of the wood surrounding our cottage-all seemed to me to have been the sustenance for Anne's imagination as they certainly were for mine. In third grade, I had changed my name to Anne-spelled-with-an-E and refused to answer to Frankie when called upon by teachers, classmates, or family. At Windy Point, I was not only called "Anne," but felt myself to be her. I wandered, swam, and boated, imagined marvellous futures for myself, and wrote absolutely terrible poetry. I really was Anne, I knew.

Rereading the series as an adult, I recognize its flaws. I am more conscious now of Lucy Maud Montgomery's Anglophone bigotries and racialism. I notice now how easily and gracefully resolved are the complexities and hardships of Anne's life. And yet, I learned lessons from her that I still value today. I learned from Anne, for example, that not all failures are catastrophic or tragic: that so long as we are able and willing to learn, to revise what we thought we knew in light of what we've learned, and to try again, failures are the opening of new possibilities for being and doing differently and better. Plus, failures can be funny if we don't take ourselves too seriously. I learned from Anne that the capacity to imagine wildly and with delight is not a character deficiency but a quality worth cultivating, so long as you are imagining something worthwhile. I learned from Anne that appearing to be ridiculous in the eyes of others is okay. I learned that caring deeply for others and yearning also to be cared for by them is okay. I learned that exuberance is okay. All of these are okay so long as we believe in and work for something worthwhile.

With particular regard to the relationship between the work of writing centres and social justice (inclusion, equity, robust multiculturalism, and multilingualism), for me, the test for what counts as worthwhile draws on the insight of peace and civil rights activist, Barbara Deming, who urges activists to recognize and honour through action "that concatenation of anger and love which 'is the concentration of one's whole being in the determination that this must change'" (as qtd in Condon, 2012, p. 147). Love and anger, of course, are not words one should use lightly with regard to the work of writing centres or, indeed, any professional labour. And yet I believe avoidance of the terms within our universities is frequently predicated upon a particularly western bifurcation of emotion and rationality according to which admitting to feeling (for none of us or, at least, no one I know, actually stops feeling when they get to work) incapacitates one's ability to think critically and carefully. 
Volume 28, 2018

http://journals.sfu.ca/cjsdw

In the fourth book of Lucy Maud Montgomery's series, Anne of the Island (1915), Anne is a student at Redmond University. At the close of her first term as an undergraduate, Anne's friend, Philippa, attempts to persuade her to visit Bolingbroke for Christmas rather than returning to Avonlea and Green Gables. Philippa promises parties and sleigh rides and the opportunity for Anne to help her decide which of her suitors to marry. To justify her refusal of the invitation, Anne describes what she will find at home where Marilla, Dora and Davey, and Mrs. Lynde await her arrival, detailing not only the house but also its environs: the orchards, water, and woods, as well as the people with whom she most closely affiliates. Philippa asserts that Green Gables sounds boring and Anne amends her story. “'Oh, but I've left out the transforming thing,' said Anne softly. 'There'll be love there, Phil - faithful, tender love, such as I'll never find anywhere else in the world - love, that's waiting for me.'” (p. 67). For Anne, love is the enabling condition for being but also for imagining, for learning, and for growth. For me, love limits our capacity to learn and to grow only to the extent that we withhold it from those we choose to meet as strangers or interlopers in what we treat as our home-spaces, or allow some facsimile of love to confine our minds to that and those who are already known to us. Our challenge, I believe, is not to abjure love in our workplaces any more than we would in our home-places but to rather exert our mindful, critical capacities to discern whether and how our habitual exercise of love (or its absence) impede our ability to engage imaginatively with the unknown: to deepen and extend our relations beyond the known.

For many years, I have begun my own efforts at imagining and experimenting with socially just writing centre leadership and one-with-one pedagogy with queries designed to invite both individual and collective discernment:

to test the ways and degrees to which we live the principles we espouse, to offer spiritual and intellectual challenge, and to encourage ongoing vision and revision of perception, consciousness, and action. The point of queries understood in this way...is to stay in consideration of the complex matters that queries raise. Queries function in some way as a guide that does not show you the way, but supports you as you find your own way. (Condon, 2012, p. 148)

The point of queries is not to enable to find definitive answers but to explore complex ideas, concepts, and principles experimentally. For me queries aid in imagining ways of trying to be and do my work differently and better. 
Volume 28, 2018

http://journals.sfu.ca/cjsdw

I conclude, then, by offering in query form those ideas, concepts, and principles that I believe align with an emergent writing centre praxis that is not merely culturally competent, but also loving (in the best sense), socially just, and pedagogically enriching for all student-writers, and for the institutions in which we labour. ${ }^{1}$

- How might we find balance between the Small-Here/Short-Now needs and interests of student writers within our current institutions and the Big-Here/Long-Now responsibilities we bear to teach with awareness of our colonial past and its aftermath: to teach toward a more just, more fair, more balanced world not only for our current students, but for the many generations of students to come?

- How might we cultivate one-with-one teaching practices richly informed by shared principles of equity and welcome; moderation and wisdom; a tolerance for complexity and ambiguity; patience and an attending willingness to both work and to wait for that consensus achievable through balanced and fair relations?

- How might we practice a willingness to engage courageously and determinedly with the evidence that injustice, intolerance, extremism, a desire for quick answers and certitudes, impatience, and self-interest continue to cause suffering particularly for students from historically oppressed and marginalized communities?

- How might we recognize the rich resource multilingualism represents for teaching and learning all languages as well as for coming to know, care for, and affiliate more deeply with one another across lines of difference?

- How might we help students to cultivate rhetorical agency by allowing-encouraging even-experimentation with language and convention in our writing centres? How might we encourage faculty to do the same in their classrooms?

- In our everyday practice as well as in principle, do we accept responsibility for reciprocity in teaching and learning relationships by opening ourselves to the possibility of learning with and from our students their languages, cultures, and rhetorical traditions even as we teach them to speak, write, and produce new knowledge in our nation's official languages?

\section{Notes}

1. For an example of discussion prompts associated with these queries that might be used in a writing centre theory and practice course with prospective tutors or in staff education, please see appendix. 
Volume 28, 2018

http://journals.sfu.ca/cjsdw

\section{Acknowledgements}

I owe a debt of gratitude to Victoria Lieggi, Jennifer Glasscock, Dacy Cramer, all of whom provided invaluable feedback as I revised this essay for publication, and to their professor, Angela Haas, who made this assistance possible. I am also grateful to the organizers of the 2017 CWCA conference and, in particular, to Kathy Block, Heather Fitzgerald, and Clare Bermingham.

\section{Appendix}

Staff Education Activity for Exploration of Queries and Discussion: An Example

\section{Overview}

Divide students or tutors into three groups. Group One will be composed of pairs experimenting with learning through playful violation of convention. Group Two will be composed of pairs experimenting with writing and tutoring multi- and/or translingual texts. And Group Three will be composed of pairs brainstorming objections and challenges that might be mounted by a worried student, a faculty colleague, a supervisor, or a university administrator to the practice of culturally inclusive one-withone pedagogy that values and draws upon multilingualism, and developing reasonable, theoretically sound, and pedagogically principled responses or counters to those objections. In Groups One and Two, both members of each pair will write initially for a few minutes, then take on and exchange roles as tutors and writers in a tutorial or consultation. In Group Three, both members of each pair will write singly, brainstorming objections. Then, working together as allies and collaborators, pairs will work to find ways to communicate to those outside of and largely unfamiliar with the work of writing centres why we might be doing what we're doing, what the value of this new and arguably experimental pedagogical practice might be, and for whom might that value be realized.

\section{Writing Prompts}

Instruct students or staff to take a moment to read the writing prompts, but urge them to avoid getting hung up on them. The idea here is to jump in courageously and just see what they can do. Participants should only write for three minutes or so in order to have time for consulting with one another.

Group One Participants: Quickly draft a paragraph in which you introduce yourself composed of a single sentence. Play with punctuation within your sentence, using as many marks as you can to suggest to your readers the relationship between ideas within your text. Your objective is to carry 
Volume 28, 2018

http://journals.sfu.ca/cjsdw

your reader with you from the surface question, problem, or perspective you have to its deeper meanings and significances, without breaking off your sentence.

Group Two Participants: Quickly draft a text in which you introduce yourself by combining, in whatever way you choose, multiple languages. Your objective is to draw upon your multiple fluencies to help your readers understand better and more deeply - - and to do so in ways that are clearly purposeful rather than accidental.

Group Three Participants: Quickly draft a list of all the obstacles and objections you can think of to doing any of the work associated with the queries (including the use of the above writing prompts) to teach students writing.

Regroup and share.

\section{References}

Condon, F. (2012). I hope I join the band: narrative, affiliation, and antiracist rhetoric. Logan, UT: Utah State University Press.

Deming, B (2011, October 18). On anger. Retrieved from http://homepage.mac.com/deyestone/onanger.html

Highway, T. (2015). A tale of monstrous extravagance: Imagining multilingualism. Edmonton, AB: The University of Alberta Press.

Montgomery, L. M. (1915). Anne of the island. New York, NY: Gressel \& Dunlap Publishers.

Phillipson, R. (1992). Linguistic imperialism. Oxford: Oxford University Press.

Saul, J. R. (2008). A fair country: Telling truths about Canada. Toronto, ON: Penguin Canada.

West, C. (2005). Prisoner of hope. CommonDreams.org. Retrieved from https://commondreams.org/view05/011135.html[Office2]

Writing Lab Newsletter Blog. (2017, May). From far and wide: The fifth annual Canadian writing centres association conference (Interview of Clare Bermingham). Retrieved from https://www.wlnjournal.org/blog/2017/05/

Young, V. A. (2010). Should writers use they own English. Iowa Journal of Cultural Studies, 12(1), 110-117. 